Love as a Peace Process? Arab-Jewish Love in the Anglophone Palestinian Novels of Naomi Shihab Nye and Samir El-Youssef

\title{
Sarah Irving
}

\section{(2) OpenEdition}

\section{Journals}

Electronic version

URL: https://journals.openedition.org/ces/4611

DOI: $10.4000 /$ ces.4611

ISSN: 2534-6695

\section{Publisher}

SEPC (Société d'études des pays du Commonwealth)

\section{Printed version}

Date of publication: 1 April 2017

Number of pages: 39-49

ISSN: 2270-0633

\section{Electronic reference}

Sarah Irving, "Love as a Peace Process? Arab-Jewish Love in the Anglophone Palestinian Novels of Naomi Shihab Nye and Samir El-Youssef", Commonwealth Essays and Studies [Online], 39.2 | 2017, Online since 03 April 2021, connection on 04 June 2021. URL: http://journals.openedition.org/ces/ 4611 ; DOI: https://doi.org/10.4000/ces.4611

\section{(c) $(1) \&$}

Commonwealth Essays and Studies is licensed under a Licence Creative Commons Attribution - Pas d'Utilisation Commerciale - Pas de Modification 4.0 International. 


\section{Love as a Peace Process?}

\section{Arab-Jewish Love in the Anglophone Palestinian Novels of Naomi Shihab Nye and Samir El-Youssef}

This article examines the portrayal of Arab-Jewish romance by Naomi Shihab Nye and Samir El-Youssef, Anglophone authors of Palestinian origin. It identifies differences

between their treatment of the theme and that of Arabophone and Hebraeophone writers, arguing that this stems from their diasporic positionalities and raising some broader questions about how literature by writers of Palestinian origin is currently studied.

Relations of love and sex which cross borders - of nation, class, ethnicity and other difference - are a trope of literature the world over, from Romeo and Juliet to modern examples such as the musical West Side Story or Peteni's Hill of Fools. Arabic fiction is no different, and this plot device has been used numerous times to probe the politics of identity and nation within the Middle East since the early twentieth century. This article looks specifically at works in which writers of Palestinian origin use romantic or sexual encounters to explore the very particular relationship between Jews and Arabs in the context of Palestine/Israel. Building on my broader research into depictions of Arab-Jewish amatory relations in Arabic novels and fiction by writers of Arab origin, in this article I discuss ways in which Palestinian Arab writers have used this trope, argue that the work of Anglophone Palestinian writers uses this device in different ways from novels by Palestinians living within historic Palestine or the Middle East and writing in Arabic or Hebrew, and suggest some tentative lessons for the discussion of "Palestinian" literature which might be drawn from this.

A glance over recent scholarly surveys of Palestinian literature reveals a range of ideas about what "Palestinian" means in this context. Bashir Abu-Manneh's recent book highlight well-known (indeed canonical) writers born in historic Palestine but who for the most part lived their adult lives in exile in other parts of the Middle East. Several other studies (Mahmud Ghanayim's The Lure of the Title, Ibrahim Taha's The Palestinian Nove) focus solely on Palestinian authors from within the State of Israel. Anna Ball and Kamal Abdel-Malak take the broadest approach, including writers and film-makers born in all parts of historic Palestine and in the diaspora, with Anna Bernard's volume falling somewhere between these and Abu-Manneh. All of the writers analysed in these studies are labelled "Palestinian," a designation which is entirely valid but which, used uncritically or without interrogation, obscures differences of biography, experience and even, I would argue, creative production.

In this essay, I examine in particular portrayals of Jewish-Arab love and romance in two Anglophone Palestinian novels, Naomi Shihab Nye's Habibi and Samir El-Youssef's A Treaty of Love. My primary reason for selecting these is that they represent the most substantial depictions in Anglophone Palestinian writing of this theme (Mischa Hiller's Sabra Zoo also deploys it, but extremely briefly). From my readings I suggest that whilst they share many of the themes and motifs of other depictions of the subject by Palestinian authors originating and living within historic Palestine, there are discernible differences in the treatment of the topic, which highlight the need for greater complexity and nuance in our use of the category "Palestinian." 
It has often been said (and, admittedly, questioned) that diaspora literatures tend to stereotype the homeland, either idealising it into a lost paradise, or condemning it as a site of irredeemable oppression (Morawska 1031, 1036-40). Reading El-Youssef and Shihab Nye's novels, I would contend that this generalisation might also be extended to the comparison of diaspora writers' treatment of the "homeland as political issue" with that of "homeland-based" writers for whom this is also a lived, everyday experience. So whilst Atallah Mansour, Anton Shammas or Sayed Kashua (all Palestinian citizens of Israel) or Rabai al-Madhoun or Ghassan Kanafani (Palestinian refugees or diasporics) undoubtedly have social and political messages to convey in their writing, and the ArabJewish relations which appear are part of this, the impression given is one of the mixed liaisons as part of a complex but quotidian flow, one loaded aspect of the many politicsladen events of everyday existence. Emotional and physical relationships clearly have allegorical purposes, but amidst many other intersecting issues. In El-Youssef and Shihab Nye's work, by contrast, one senses that mixed relationships are clearly flagged as the key allegory, metaphor or theme through which a political point is expressed. Where Mansour, Kanafani, Shammas, Madhoun or Kashua use Arab-Jewish romances as one of many ways in which the tensions and complexities of Palestinian life are conveyed, in El-Youssef and Shihab Nye's novels, the plot is clearly constructed around this as "The Big Issue" of the book. To call this use of the theme didactic risks being seen as denigrating them, which is not my intention, but it captures the strength of a purpose, which goes beyond the use of allegory to complicate and disrupt discourses.

This is not to argue that Palestinian writers in Arabic and Hebrew do not write with political purpose, but to suggest that the singularity and clarity of that purpose, and its response to specific incidents and conversations in Palestinian political life, is significantly greater in these Anglophone diasporic examples. Nor is it to claim that all diaspora literature is built around a political aim, or even that all Palestinian refugee literature is so constructed. But I do suggest that Palestinian writers in diaspora may feel - whether as desire or compulsion - a necessity of tackling issues of refugees, exile and "right of return," in line with Stuart Hall's notion of the "burden of representation." Where Hall sees this as pressure to present one's people in the best possible light (27-30), I suggest in this Palestinian case it is the urge to advocate for one's people (Shihab Nye) or make political arguments about the situation in which they are embroiled (El-Youssef).

Indeed, Edward Said imposed on his compatriot intellectuals a double responsibility: engagement as a duty of the exilic author (Representations 59), and the obligation to speak and act for one's Palestinian people (Reith Lectures 6). What greater pressure could be imagined for many diaspora Palestinian writers? This may also be linked to the diasporic or hybrid subject's quest for identity, or their experiences of racism and marginalisation in the host country. Sometimes, as in El-Youssef's case (and as Hall discusses in the case of Hanif Kureishi, 31), the writer resists - but as we can see in the figures of the narrator's group of Arab drinking-buddies, that resistance is also what shapes the work, it still demands the foregrounding of a politicised position. For Anglophone writers, this dynamic of obligation and duty seems all the greater. Unlike those Palestinian authors working in Arabic or Hebrew, whose writing can be seen as part of a conversation in the homeland in which a certain amount of shared understanding exists, the diasporic "burden" as articulated by Hall and Said includes the necessity not just of advocating for the people with whom one is identified, but also explaining and representing the issue 
and its complexities to often uninterested, ill-informed or hostile audiences in the host country. If the politics of Anglophone Palestinian novels are often placed firmly in the foreground, in comparison with the more subtle approaches of writers from amongst Palestinian citizens of Israel or the Occupied Territories, we need to consider this at least to some extent as a function of the reception their authors are seeking, and their greater proximity to audiences to whom they must convey a particular message.

In short, I argue that writing by authors in the Palestinian diaspora is shaped just as much by the writer's diasporic experience, including the pressures stemming from that diasporicity (hybridity and/or non-Palestinian origins and milieu) as it is by their "Palestinianness." There is a tendency for works which are (through translation or Anglophone authorship) more linguistically accessible to Western audiences to become "canon" and/or popular, with concomitant impacts on the academic treatment of works by writers of Palestinian origin more generally. I would suggest that the kinds of differences and tendencies visible in Shihab Nye and El-Youssef's work raise questions about what we mean when we write about Palestinian literature, how we should go about this task, and the extent to which some recent approaches to Palestinian literature - particularly those reliant upon translated and Anglophone works - carry within them a danger of stripping out the historical specificities of Palestinian writers and experiences. Anna Ball, writing on Naomi Shihab Nye and Suheir Hammad, foregrounds "their identity as specifically Palestinian Americans" (Ball 147, emphasis in original). I suggest that to understand the work of writers such as Shihab Nye, and El-Youssef, we need to reverse the italicisation, and consider what it means for them also to be Palestinian Americans and Palestinian British.

An increasing body of academic literature looks at Anglophone Palestinian writing and Arabic works in translation; the potential for this to cause radical distortions in how national literatures are viewed, especially in relation to colonialism, has been explored most recently and comprehensively by Aamir Mufti in Forget English! Indeed, Bart Moore-Gilbert highlights the dangers of this practice for his own engagement in the field, with translational choices prompting misreadings and misleading conclusions (6), although it has been defended by scholars such as Anna Ball (13) as potentially destabilising Anglophone tendencies in literary scholarship. I suggest, though, that to discuss Anglophone writing by writers of Palestinian origin alongside works translated from Arabic or Hebrew into English under a unitary category of Palestinian, without paying close attention to authorial experiences and life-stories, bears within it certain dangers. Amongst these are the elision of internal differences within Palestinian experiences, and a lack of recognition of the power dynamics between Anglophone writers and those who must be mediated by translation and are condemned by Western publishers as "difficult to sell" because of the perception that translated works are unpopular with consumers.

\section{Palestinian Writers and Cross-border Sexuality}

In addition to these issues within the study of Palestinian literature, broadly defined, the literature of Arab-Jewish and Muslim-Jewish romance also differs in Palestinian fiction from that by authors from other parts of the Arabic-speaking world. For writers from places such as Egypt, Iraq and Yemen, themes of nostalgia and past longing permeate 
stories set in or referring to the large, socially and culturally significant Jewish communities present in those countries until the early 1950s (Irving Romance 347 and Copts, Islamists 3, 6). In many parts of the Arab world, Jews had been established parts of local communities for centuries, if not millennia, and whilst representations of co-existence and harmony may now be over-romanticised, Islamic countries were certainly less discriminatory environments than Christian Europe (Veinstein 171-5; Laurens 269-72). Many novels by authors writing in Arabic reflect this idealisation, using historical images of Muslim-Jewish interaction and particularly romance to express the desirability of past tolerance and diversity (Irving Romance 346, 359, and Copts, Islamists 8). In Palestine, however, the meaning of "Jewish" and the figure of the Jew was much more radically destabilised, and at an earlier date. Awareness of the potential threat posed by European Jewish settlement was mentioned in the regional press from at least the first decade of the twentieth century (Gribetz 2, 37, 130) and for those actually displaced by Zionist colonies the issue was very concrete. To post-1948 Palestinians (including writers), Jews represented not an ancient, departed, part of the community, but a Zionist movement, which had made many of them refugees and others the inhabitants of occupied land. For Palestinians living in the occupied territories, since the early 1990s the only encounter with actual Jewish individuals is likely to have been Israeli soldiers or settlers, whilst for those living within the Israel, Jews are co-citizens but within a situation of considerable tension and discrimination.

Literature itself, for Palestinian writers, has often been seen as a direct tool of struggle, resistance and mobilisation (Ball 3, 61; Brenner 113-6; Harlow; Kanafani 1968). As highlighted above, though, there are limits on how far it is possible to talk about "Palestinian" literature. Although writers of Palestinian origin share a common cultural origin and the common fact of the Nakba (the Palestinian "catastrophe" of the establishment of the State of Israel in 1948), their actual lived experiences can be hugely divergent, varying between military occupation, refugee camps, economically privileged diaspora or paperless displacement. The Palestinian subject can be the classic "Deleuzian nomad" in a free-flowing globalised world or (perhaps more probably), someone for whom the "flux and fluidity" of diaspora is "deeply oppressive" (Ball 133). Similar diversity characterises any Palestinian readership, while closed borders have prevented the free movement of printed material (as well as human beings) between sections of historic Palestine and between them and the wider Arab world. We might also apply to literature Alexander's argument $(153,167)$ that the absence of bodies to fund, unite and support Palestinian film-makers (in contrast to the national funding agencies existent in most states) has affected the extent to which we can speak of the common development of a literature which can be identified with the nation. As I have argued above, the ways in which authors of diverse Palestinian origins write romantic themes highlights the necessity of understanding the impact of place, origin and hybridity on their work.

It has become a commonplace that, as in literatures from around the world, Palestinian writing about the nation and homeland is often gendered, and expressed using "the imagery of desire, sexual union, penetration, fertilisation, love and family" (Ball 21, 30) and of rape and sexual possession (Layoun 14-16, 148-50). Mahmoud Darwish's images of Palestine as both mother and lover are perhaps the most famous examples of this feminisation of the homeland. As Anna Ball notes, Rashid Husain's poetry explicitly uses the idea of marriage to set out the issue of Palestine, with the land as a girl having 
to choose between her old lover, the Palestinian Arabs, and her new Zionist suitor (358), a notion also implied in the 1987 Palestinian film Wedding in Galilee (Layoun 35-8). But, as other scholars have outlined, the actual political and social environment in which many Palestinian men exist is deeply emasculating (Muhanna 3-4 et passim), disrupting this gendered scheme and highlighting - as Ghassan Kanafani expresses in his novella Men in the Sun - their ultimate powerlessness over their home situations, their political environment, and their own bodies (Abu-Manneh 78-81).

The earliest uses by writers in Arabic of Arab-Jewish sexual and romantic encounters to explore relations between the two peoples occur in fiction by Palestinian writers. In 1919 or 1920, Khalil Baydas, an educator and translator from Russian into Arabic, published Al-waräth (The Heir), a novel in which a young Syrian, living in Egypt, loses his dignity and inheritance to a Jewish woman, who is depicted as cruel, wanton and greedy. Abdel-Malek suggests that Baydas had a "didactic purpose," trying to scare Palestinian youngsters away from Jewish lovers (24). Jayyusi criticises the novel more strongly, calling its depiction of Jews "pejorative, Shylock-like" and of Arab society as depending on "inherited morals and a traditional outlook," claiming that the novel relies on essentialist stereotypes rather than a critique of the Zionist project (13). This use of the Jewish woman as a symbol of decadent, urban modernity, set against the upstanding rural Palestinian/Arab male, continues into the post-Nakba period with Ghassan Kanafani's short story collection 'An al-rijäl wal-banädiq (Of Men and Guns, 1968). Here, the character of Eva is part of the urban-Jewish nexus which separates Dr Qassim for whose education his peasant father has made great sacrifices - from his family and identity (Palestine's Children 59-61, 77-8, 98).

In more recent works from Palestinian writers that adopt the cross-border romantic theme, we find a greater diversity of attitudes, with the depiction of Arab-Jewish relationships often shifting and apparently influenced by the positionality of the writer. These various locations - geographical, religious, social, linguistic - include Palestinians living within the state of Israel (Atallah Mansour's In A New Light (Hebrew, 1966), Samih al-Qasim's The Last Picture in the Album/Al-süra al-akhira fi al-album, (Arabic, 1980); Anton Shammas's Arabesques/Arabeskot (Hebrew, 1988)); those living in the Occupied Territories (Yahya Yakhluf's The River Bathes in the Lake/Nahr yastaham fi al-buhayra; Ghassan Zaqtan's An Old Carriage with Curtains, 2011); Palestinians living in diaspora and writing in Arabic (Rabai al-Madhoun's The Lady from Tel Aviv/Al-sitt min Tel Abib, 2009) and those living in diaspora and writing in English (Naomi Shihab Nye's Habibi, 1999, Samir el-Youssef's A Treaty of Love, 2008, and Mischa Hiller's Sabra Zoo, 2010). In considering the commonalities between the depictions of Arab-Jewish love in Shihab Nye and el-Youssef's works, I argue that they employ this motif in differing but more openly ideological ways which contrast with the more everyday appearance of Jewish objects of love in novels by Palestinians writing at closer proximity to such experiences.

\section{Naomi Shihab Nye and Samir El-Youssef}

My analysis focuses on to two novels set during the 1990s, against the background of the Oslo Peace Process and hopes for a solution to the Palestinian refugee crisis and search for a state. The first, Habibi, is a young adult novel by Naomi Shihab Nye, an American writer of Palestinian and American parentage who grew up partly in Jerusalem and is best known for her poetry. In the semi-autobiographical Habibi Shihab Nye 
portrays a Palestinian-American teenager whose mixed family move to Jerusalem at a time of optimism in Arab-Israeli relations, and who falls in love with a Jewish boy. The second, Treaty of Love, is by Samir el-Youssef, a writer born in Rashidiyyeh camp in Lebanon to a Sunni father and a Shi'i mother, and resident in London since 1990. ElYoussef has been a controversial voice for many Palestinian writers and political commentators, as he rejects the idea of a Palestinian "right of return," urges dialogue with Israel, and published Gaza Blues, a joint collection of short stories with Israeli writer Etgar Keret (Ball, 179; Reisz). El-Youssef's previous works, which feature themes such as suicide, oppression of women, and homophobic violence, can be seen as offering a deconstruction and rejection of mainstream Palestinian masculinity (Ball 80). Treaty of Love depicts a love affair between a Palestinian Arab man and an Israeli Jewish woman; the relationship takes place in London during the 1990s and is explicitly used to trace the rise and fall of the peace process.

Shihab Nye and El-Youssef both use romantic relationships to evaluate the possibilities (and possible failures) of the Oslo peace process, initiated in 1993 with an agreement signed by Yasser Arafat and Yitzhak Rabin. It is notable, however, that Shihab Nye's narrative offers an optimistic take on the political process, something which could be seen as credible when the novel appeared in 1997. By the time El-Youssef's work was published in 2008, however, all that could be believably expressed was a dissection of the process's failure and its descent into bad faith and violence, as reflected in his novel's traumatic ending.

Naomi Shihab Nye's Habibi is a young adult novel, the protagonist of which is Liyana Abboud, a teenage girl whose father is (Christian) Palestinian and mother American (of European origin). Strategically establishing itself as a teen novel rather than a didactic work, the book opens with the main character's musings on her first ever kiss. She is then confronted with the information that her parents are taking the family back to her father's home city of Jerusalem, where conditions are perceived as safe enough for him to want his children to grow up in his own culture. The plot reflects the real-life decision of significant numbers of diaspora Palestinians to return during the 1990s, in the hope that the developing political settlement would result in an independent state; it also, however, mirrors the discourse of "return" which was key to the Zionist movement and later to Palestinian politics. During its exploration of the difficulties Liyana and her younger brother experience in transitioning to a new cultural environment and familial expectations, Liyana befriends and becomes romantically involved with a teenage boy, Omer, who she discovers some time into their friendship is Jewish.

The assertion of Palestine as a potential site of peace and cross-cultural tolerance is made even before the Abboud family's return. At school in America, Liyana is required to write an essay on Jerusalem in which she chooses to highlight how, as a child, her father "and the kids on the street liked to trade desserts after dinner" (Nye 28). Jewish, "Greek" and "Arab" (signifying Christian and Arab, respectively) children are depicted as playing together harmoniously and "nobody [...] thought much about being Arabs or Jews" (Nye 28). Modern-day Palestinians are shown as one people, any differences between Christians and Muslims subsumed beneath a national identity, and although the extended Abboud family are Muslim, more detail is actually given about Christian beliefs and connection to Palestine. The family's encounters with Jewish Israelis in 
the first days of their return are, however, traumatic, with depictions including hostile airport officials and their uncle's humiliation by a checkpoint guard on the journey to Jerusalem $(34-7,44)$. The sense of nostalgia expressed in Liyana's essay is quickly dispelled as she realises that instead of a "halo" the city has "diesel fumes" (51). And, in terms of thinking of identity as articulated in amatory terms, the complexities of Liyana's mixed-parentage, migrant subjectivity are suggested by her father's anger when a relative asks for the fourteen-year-old girl to be engaged to his son, thus asserting the girl's cultural distance from "archaic customs" in the homeland as well as from the Israeli occupiers (60). At a family discussion, the terminology of love is also used to explain current tensions between Jews and Arabs, understood through the idea that people who love one another also fight and that the two peoples are "bonded for life. Whether they like it or not" (73).

At the start of Liyana's friendship with the Israeli Jewish boy Omer she mistakes his name for the Arabic Omar, flagging the similarities between the names and cultures, and at their first arranged date, they share a plate of the quintessentially Middle Eastern dish, hummus (153). Omer's love of walking, museums and countryside establish his connection to history and place, and both teenagers are depicted as outsiders amongst their age group, establishing the possibility that they can be "different" in their commitment to peace. Liyana's father's immediate reaction of anger over the relationship - rooted in his fear for Liyana's safety and reputation - is, however, explicitly compared to his idealised childhood tales of Arab-Jewish coexistence (171).

The religious identities of Liyana and Omer are, indeed, complicated in Shihab Nye's approach. Liyana's immediate family do not practice the father's Islamic faith but instead are portrayed as having a wide-ranging set of beliefs which embrace Buddhist and Hindu elements and which reject religious truth claims of all kinds (173-8). Omer is attached to his Jewish identity - his "Jewish hands, Jewish bones, Jewish stories and [...] Jewish soul" but in a secularised way which involves celebrating "a few special-holiday things" (176). This could be seen as the two teenagers finding their own, personally authentic sense of identity which allows them to bridge externally-imposed divisions. On the other hand, we could read the novel as suggesting that it is only by renouncing their communities' values and identities - by adopting a secularised, deracinated notion of self and adhering to what Liyana's father calls "moderate [...] liberal" ideas (179) which many Palestinians and Israelis would find deeply problematic - that the two can meet. Following the novel's main exploration of the pair's religious and ethnic identities, they are said to have "talked more about wanderers and gypsies and vagabonds longer than they talked about anything else," underscoring this sense of dislocation and strangeness and marking the young couple as members of the kind of post-identitarian nomads mentioned above, transcending ethnic and religious boundaries.

I believe that Shihab Nye's portrayal of the affection between Liyana and Omer needs to be read not only through the lens of the novel's explicit message of Palestinian-Israeli peace, but also in connection to the author's widely-discussed position as a specific kind of activist Arab-American/Palestinian-American writer, who has also referred to herself as a "wandering poet" (BarclayAgency.com). The Palestinian-American poet Suheir Hammad, herself strongly influenced by the Black American culture of her childhood, has highlighted both Shihab Nye's explicit literary activism in US community relations and her hybridity not with Hammad's urban milieu but with a more mains- 
tream/white US culture (Knopf-Newman 78-9). Much analysis of Shihab Nye's work has also focused on her use of domestic detail and everyday familial references to build a sense of warmth, strength and spirituality which - as seen in Habibi - draw out deeper strands of (often but not exclusively) female wisdom which transcend cruder social structures (Kutrieh 3, 8-14). As such, Shihab Nye could be said to have constructed for herself a distinctive authorial persona, incorporating an activism which is intertwined with the Palestinian aspects of her heritage but which evades, or rejects, the nationalist or feminist "burden of representation" imposed on many creatives, especially those in the diaspora, and especially women (Elia 141; Friedman 29; Valassopoulos 93-4).

Samir El-Youssef's 2008 novel A Treaty of Love, meanwhile, centres on a love affair, which explicitly tracks the rise and fall of the Oslo peace process. Each chapter opens with two or three lines commenting on political events or progress and on the main events in the relationship between Ibrahim (a Palestinian raised in a Lebanese refugee camp) and Ruth (an Israeli living in London). Examples range from: "First we had peace; there was that notorious handshake between Arafat and Rabin, and then I met Ruth and started to think about making a film" (11) to "First Sharon visited Haram alSharif, then the second intifada started, then I wanted to reveal to Ruth what had happened to Maryam. Instead we fought" (200). The initial widespread optimism hinging on the Oslo Accords and the Arafat-Rabin encounter in Washington parallels Ibrahim and Ruth's meeting at a party, at which their hosts deliberately introduce them as a reference to the political atmosphere (35). Major events over the ensuing decade are then mentioned in most chapter openings, combined with personal developments and often used to cast a pall across even apparently happy news, prefiguring their role in the relationship's apparently inevitable decline. Rabin's 1995 assassination, for instance, is paired with Ibrahim and Ruth moving in together (44) and the growing frequency of suicide bombings with their attempt to improve their relationship by going on holiday (69).

Despite this apparently obvious and crude pairing of the relationship between an exiled Palestinian and an Israeli with the failed negotiations of the 1990s, El-Youssef's novel actually offers a more complex discussion of the two identities and their encounters. In the earlier stages of the novel, there is a repeated emphasis on the similarities between Ibrahim and Ruth. They have similar personal habits, seeing each other as "like a long-lost relative," "not too foreign" in comparison with other people each had met in London, and with a "long common history" (El-Youssef 7, 34, 37, 39). Meeting in London allows El-Youssef to frame them at the start as a less idealistic version of Shihab Nye's Deleuzian nomads, transcending their respective nationalities in a foreign space. Their overlapping experiences include traumas stemming from their countries' conflict, but are also, more positively, rooted in a Middle Eastern geography - "childhood memories of the Lebanese and Israeli shores of the Mediterranean flooded back into our present" - reinforcing the sense of a common Arab-Jewish identity which is not just founded in their personal similarities but in a shared regional origin $(61,68)$.

As the relationship deteriorates, however, the shared characteristics become destructive and damaging, with Ibrahim and Ruth each locked into identical patterns of simultaneous rejection and possession $(9,175)$, to the point where their identities become blurred and confused (19). Ibrahim's feeling that "I cannot even ask her to leave because that would be as if I was leaving myself" (8) has a triple significance in this context: it is an expression of sexual co-dependence, but as a political statement it evokes both an 
underlying identicality of Arab and Jew, and a sense of the unbreakable death-grip in which Palestine and Israel as political actors were locked by the end of the Oslo period.

Whereas non-Palestinian Arab writers such as Bahaa Abdelmegid and Mahmoud Saeed explicitly reject the conflation of Jewish with Israeli identities (Irving Romance 354-5, Copts, Islamists 7, 9), El-Youssef follows both the dominant Israeli rhetoric and the prevailing political environment in seeing Ruth as intrinsically representing the Israeli nation-state and a longer, more essential Middle Eastern Jewish selfhood. In $A$ Treaty of Love, Jews and Arabs are, we are repeatedly told, almost identical, but in the political framework of the divisions between Israel and the Arab nations as states, this identicality is either insufficient to sustain a relationship, or indeed is its downfall. Despite the hopes that Ruth and Ibrahim express at the start of their affair, emphasising their likeness and commonalities, in their end their "shaky experiment [is] doomed to failure" (65), with a rushed, poorly thought-through cohabitation mirroring the flawed negotiations of the Oslo Accords.

As with Shihab Nye, autobiographical elements are plain in El-Youssef's novel, in the protagonist's emigration from the camps of Lebanon to London, and his rejection of Palestinian and Arab nationalist views. Unlike Shihab Nye, however, El-Youssef's critical views on Palestinian nationalism and mainstream Palestinian discourses of identity and resistance combine with the later historical date of his novel to present a much darker, more cynical - not to say nihilistic - image of Palestinian-Israeli/Arab-Jewish relations. While both novels articulate an underlying sense that, in the end, Jews and Arabs are fundamentally similar, in El-Youssef's version this likeness, distorted by politics and power relations, descends into a tightly-bound and inescapable downward spiral.

\section{Conclusion}

As this examination shows, for Shihab Nye and El-Youssef, sex and love between Jews and Arabs is not a subtle allegory woven into the varying plot lines of a story. Rather, the theme is placed front and centre in their novels. In Habibi, Shihab Nye's eloquent, accessible writing is utilised to advocate a specific position on the question of Palestine, isolating many of the political points made by opponents of Palestinian rights and answering them through the device of Liyana and Omer's relationship, the discussions they have about their identities and the reactions of Liyana's relatives to the IsraeliJewish Omer. In A Treaty of Love, meanwhile, El-Youssef even more openly uses matters of love and sex to discuss the downward trajectory of the Oslo peace process and the author's energetic rejection of identity politics as a solution; as such, the political aspect of El-Youssef's project structures the entire work.

For an author of Palestinian origin to depict romantic or sexual relations between Jews and Arabs cannot, in the current climate, be anything but a political act. But where representations of this theme in Arabic and Hebrew novels weave it into plots in which it is often a supporting theme, one amongst many, these two diaspora authors foreground the subject and the political points they are making. As outlined in the first half of this article, I believe that this difference stems at least in part from the differing environments in which the writers work and the audiences they face. Where contemporary Palestinian writers working in Arabic or Hebrew use the device of a cross-border sexuality to disrupt discourses of separation or to assert the humanity and commonality 
of Arabs and Jews despite political divisions, Shihab Nye and El-Youssef seem to be facing different readerships. Instead, they present themselves to these more "foreign" audiences as insiders (Palestinians), with interior knowledge of the situation and the emotions it engenders. On the other hand, they also appear as outsiders (diasporic figures) who experience a sense of duty or compulsion to articulate a particular position or cause. This, I argue, demands that we read their works in a slightly different way, acknowledging not only the circumstances of their production, but also the aims and intended audiences which lie behind their writings. And as such, it also highlights the need to take such issues into account when we read Anglophone diasporic Palestinian writing next to that of Palestinians in other environments, whether in translation or in the languages of the Levant.

Sarah IRVING

Edge Hill University (United Kingdom)

\section{Works Cited}

"Naomi Shihab Nye." 18 July 2016 <http://barclayagency.com/site/speaker/naomi-shihab-nye>.

AbDel-MALEK, Kamal. The Rhetoric of Violence: Arab-Jewish Encounters in Contemporary Palestinian Literature and Film. New York: Palgrave Macmillan, 2005.

Abu-Mannen, Bashir. The Palestinian Novel: From 1948 to the Present. Cambridge, UK: Cambridge UP, 2016

Alexander, Livia. "Is there a Palestinian Cinema? The National and Transnational in Palestinian Film Production." Palestine, Israel, and the Politics of Popular Culture. Ed. Rebecca Stein and Ted Swedenburg. Durham, NC: Duke UP, 2005. 150-74.

Ball, Anna. Palestinian Literature and Film in Postcolonial Feminist Perspective. London: Routledge, 2012.

Bernard, Anna. Rhetorics of Belonging: Nation, Narration, and Israel/Palestine. Liverpool: Liverpool UP, 2013.

Brenner, Rachel Feldhay. Inextricably Bonded: Israeli and Arab Jewish Writers Re-visioning Culture. Madison: Wisconsin UP, 2003.

EliA, Nada. "The Burden of Representation: When Palestinians Speak Out." Arab \& Arab American Feminisms: Gender, Violence, \& Belonging. Ed. Rabab Abdulhadi, Evelyn Alsultany, Nadine Naber. Syracuse: Syracuse UP, 2011.

Friedman, Yael. "Guises of Transnationalism in Israel/Palestine: A Few Notes on 5 Broken Cameras." Transnational Cinemas 6:1 (2015): 17-32.

GHanayim, Mahmud. The Lure of the Title: Text and Context in Palestinian Fiction, 1948-2012. Wiesbaden: Harrassowitz Verlag, 2015

Gribetz, Jonathan. Defining Neigbbors: Religion, Race, and the Early Zionist-Arab Encounter. Princeton: Princeton UP, 2014.

Hall, Stuart. "New Ethnicities." Black Film British Cinema. Ed. Kobena Mercer. London: British Film Institute/Institute for Contemporary Arts, Document 7 (1988): 27-31.

HARLow, Barbara. Resistance Literature. London: Methuen, 1987.

Irving, Sarah. "Gender, Conflict and Muslim-Jewish Romance: Reading 'Ali Al-Muqri’s The Handsome Jew and Mahmoud Saeed's The World Through the Eyes of Angels." Journal of Middle East Women's Studies 12.3 (Autumn 2016): 343-62.

—. "Copts, Islamists and Jews: Gender, Minorities, Hybridity (and its Limits) in Two Novellas by Bahaa Abdelmegid.” New Middle Eastern Studies 6 (2016): 1-15.

JAYYusi, Salma Khadra, ed. Anthology of Modern Palestinian Literature. New York: Columbia UP, 1992.

Kanafani, Ghassan. Palestine's Children: Returning to Haifa and Other Stories. Trans. Barbara Harlow and Karen Riley. Boulder: Lynne Reiner, 2000.

_. Al-Adab al-Filastini al-Muqawim, 1948-1968 (Palestinian Resistance Literature, 1948-1968). Beirut: Dār al-Ādāb, 1968.

Knopf-Newman, Marcy. "Interview with Suheir Hammad.” MELUS 31.4 (Winter, 2006): 71-91.

Kutrien, Marcia. "Images of Palestinians in the Work of Naomi Shihab Nye." Journal of King Abdulazir. University 15 (2007): 3-16. 
Laurens, Henry. "Judaism and the Religious Denominational Community in the Near East." History of Jewish-Muslim Relations: From the Origins to the Present Day. Ed. Meddeb, Abdelwahab, and Benjamin Stora. Princeton: Princeton UP, 2013. 269-79.

Layoun, Mary. Wedded to the Land: Gender, Boundaries, and Nationalism in Crisis. Durham, NC: Duke UP, 2001.

Moore-GilberT, Bart. "Palestine, Postcolonialism and Pessoptimism.” Interventions 18 (2016): 1-34.

Morawska, Ewa. "Diaspora' Diasporas' Representations of their Homelands: Exploring the Polymorphs." Ethnic and Racial Studies 34.6 (2011): 1029-48.

MuFT, Aamir. Forget English! Orientalisms and World Literatures. Cambridge, MA: Harvard UP, 2016.

Munanna, Aitemad. Agency and Gender in Gaza: Masculinity, Femininity and Family during the Second Intifada. Farnham: Ashgate, 2013.

OMER-Sherman, Ranen, Imagining the Kibbutr: Visions of Utopia in Literature and Film. Pennsylvania: Pennsylvania State UP, 2015.

Reisz, Matthew J. "Samir el-Youssef: At Home with the Heretic". 19 January $2007<$ http://www. independent.co.uk/arts-entertainment/books/features/samir-el-youssef-at-home-with-theheretic-432650.html>.

SAID, Edward. "Holding Nations and Traditions at Bay." Representations of the Intellectual. The 1993 Reith Lectures. London: Vintage, 1994. 25-46.

ShiHAB Nye, Naomi. Habibi. New York: Simon \& Schuster, 1999.

Valassopoulos, Anastasia. Contemporary Arab Women Writers: Cultural Expression in Context. Abingdon: Routledge, 2008.

Veinstein, Gilles. "Jews and Muslims in the Ottoman Empire." History of Jenish-Muslim Relations: From the Origins to the Present Day. Meddeb and Stora 171-95. 